\title{
The Potential of a Commercial Product based on Bacillus thruingiensis Cry1A-Cry2A Toxins as an Immunogen and Adjuvant
}

\author{
Gloria Guillermina Guerrero ${ }^{1 *}$, Favela-Hernández $\mathrm{JM}^{2}$ and Balderas-Renteria $\mathrm{I}^{3}$ \\ 'Universidad Autónoma de Zacatecas, Unidad Académica de Ciencias Biológicas, Lab de Immunobiologia, Campus II-UAZ, Zacatecas, Zac, México \\ ${ }^{2}$ Instituto Multidisciplinario de Ciencias (AVICENA), Campus Torreón, Coahuila, México \\ ${ }^{3}$ Universidad Autónoma de Nuevo León, Departamento de Investigación y Posgrado de la, Facultad de Ciencias Químicas, Lab de Ingeniería \\ Genética y Genómica, Monterrey, Nvo León, México
}

\section{Article Info}

*Corresponding author:
Gloria Guillermina Guerrero
Profesor- Researcher
Unidad Académica de Ciencias Biológicas.
Universidad Autónoma de Zacatecas
Av. Preparatoria S/N. Campus
Universitario II. Col Agronómica, CP
98066. Zacatecas
Zacatecas, Mexico
Tel: (+52) 014921564376
E-mail: gloriaguillermina@uaz.edu.mx
$\quad$ gloguerrero9@gmail.com

Received: August 28, 2018

Accepted: September 14, 2018

Published: December 26, 2018

Citation: Guerrero GG. Favela-Hernández JM, Balderas RI. The Potential of a Commercial Product based on Bacillus thruingiensis Cry1ACry2A Toxins as an Immunogen and Adjuvant Madridge J Immunol. 2018; 3(1): 58-64. doi: $10.18689 / \mathrm{mjim}-1000114$

Copyright: () 2018 The Author(s). This work is licensed under a Creative Commons Attribution 4.0 International License, which permits unrestricted use, distribution, and reproduction in any medium, provided the original work is properly cited.

Published by Madridge Publishers

\begin{abstract}
Bacillus thruingiensis Cry toxins are strong immunogen adjuvants and potential carriers of clinically important antigens, However, there are still safety and biological concerns for clinical use. In the present work, strong immunogenicity were measured through antibody production (IgM, $\lg \mathrm{A}, \lg \mathrm{G}$ subclass) (in serum and broncheo-alveolar washes) and pro-inflammatory/anti-inflammatory cytokine induction after intranasal/ oral immunization. First, we found that Th1-Th2 cytokines were induced (TNF- $\alpha$, IFN- $\gamma$, IL-6, IL-4) as well as IL-17 and IL-10. Second, a remarkable higher systemic IFN- $\gamma$ and TNF- $\alpha$ induction after oral immunization. These data were strengthened because no toxic effect in mammalian cells (pneumocytes classs II-A549 human cell line) at $10 \mu \mathrm{g} / \mathrm{ml}$ was observed. Conversely; Cry1A toxins acted as an adjuvant of BCG vaccine immunity after A549 co-stimulation with BCG, a boost in the Th1-type response (IFN- $\gamma$ and IL-12) was induced. In summary, all the data reported here, show that a commercial product based on $B$. thruingiensis Cry1A-Cry2A toxins is an strong immunogen and adjuvant both properties could account for the development of non toxic therapeutic agents.
\end{abstract}

Keywords: Bacillus thruingiensis, Cry1A toxins, Cry2A IL-17, IFN- $\gamma$, IgG subclasses.

\section{Introduction}

Bacillus thruingiensis (Bt) Cry toxins belongs to a multigenic family of crystalline proteins, or "Cry" [1-3]. In a previous work, we have been shown that $B t \mathrm{tCry} 1 \mathrm{~A}(1 \mathrm{Aa}, 1 \mathrm{Ab}$, $1 \mathrm{Ac})$ induce strong immune responses after intraperitoneal or mucosal administration (nasal) [4-8]. However, most of the studies have centered in the protoxin Cry1Ac (pCry1Ac), a strong immunogen, adjuvant and carrier [7-12]. The mechanism of these abilities remains to be defined. At this point, some studies have addressed this issue. For example, it has been demonstrated that there is an initial interaction of pCry1Ac with molecules like receptor [13]; whereas in monocytes elicited a higher expression of FcRn receptor after immunized with pCry1Ac [14] or with mice immune cells [15-16].

From the literature, it is well known that one of the most potent immunogen and adjuvant described until now is the one produced by Vibrio cholerae [17-21]. These properties are highlighted because after intranasal immunization of mice with small doses of cholera toxin, it was sufficient to induce Th17- cellular immune responses to bystander antigens $[19 ; 20]$. This type of cellular immune response was necessary to exert their adjuvant effect at mucosal sites and protective effects against spores of Bacillus anthrax [20]. Moreover, as an adjuvant, cholera toxin or the subunit B based candidates could provide with a promising alternative for human use. However, due to their inherent toxicity of cholera toxin as well as the high cost of engineering subunit B formulation, we think that Cry toxins could be a potential alternative as an adjuvant for clinical use. 
The safety and biological effects of Cry toxins in mammals have been revisited recently [22]. In addition, several other reports have shown that under specific experimental settings, $B t$ Cry toxins could exert a toxic effect or deleterious [23-27]

Thus, for example it has been shown that mice feeded with transgenic maize and or purified Cry1Ab toxin, elicited humoral and cellular immune responses in serum of mice after sensitization by intraperitoneal or intragastric route. Not induction of IgE or toxicity was seen [26-29]. Moreover, a very recent report suggest that $B t$ Cry toxins could be used for human purposes but only if they are administered by mucosal, and nor by systemic or parenteral route [30]. The data reported here, highlight and strengthened these studies [30] that indicate that $B$. thruingiensis Cry toxins are safe only after mucosal immunization. In the present work, we found that after either in vivo (BALB/c mice) or in vitro (pneumocytes class II)(A549 human cell line), the commercial product based on Cry1A-Cry2A toxins showed a dichotomy action; either as a strong immunogen through mucosal immunization, of mice and as an adjuvant of BCG vaccine immunity in vitro (increase in the Th1 type cytokine induction (IFN- $\gamma / \mathrm{IL}-12$ ), a novel property that might explored and account for the development of non-toxic therapeutic alternatives

\section{Material and Methods}

\section{Animals}

Pathogen-free adult (seven to eight weeks old) BALB/C mice were obtained from Harlan, Co, USA and were housed and maintained in the animal facilities of the campus UACBUAZ (Zacatecas, Zac. Mexico). All animal experiments were performed according to the protocols approved by bioethical committee of the University Autonome of Zacatecas. Campus $X X I$ and conformed to National Community guidelines (SENASICA AUT-B-C-0514-011).

\section{Immunizations}

Groups of seven to eight weeks- old BALB/C female mice were immunized intranasally (i.n.) or by oral route with sterilephosphate buffered saline (PBS), or with a commercial based Cry1A-Cry2A toxin preparation Bactospeine ${ }^{\circledR}$ DF (Valent BioSciences de México, S.A. de C.V.) $(2.5 \mu \mathrm{g} / \mathrm{ml})$ in a final volumen of 10 to $20 \mu \mathrm{l}$. One week after first immunization, at intervals of once weeks during a total of three weeks, each group of mice were immunized by i.n. and/or oral route with PBS or comercial product based on Cry1A-Cry2A toxins (Bactospeine). Two weeks after the last immunization, mice were sacrificed, accordingly to the bioethics guidelines of UAZ (SENASICA AUT-B-C-0514-011). Serum and broncho-alveolar lavages were obtained and maintained at $-80^{\circ} \mathrm{C}$ until use.

\section{Enzyme-linked immunosorbent assays}

To measure specific anti-Cry1A toxins levels in serum and/ or, bronco-alveolar fluids (BAL), standard indirect ELISA were perfomed as described previously. Briefly, 96-well plates (Nunc Maxisorb, NY) were coated overnight at $4^{\circ} \mathrm{C}$ with $1 \mu \mathrm{g}$ per well of Cry1A toxins dissolved in carbonate buffer (pH 9.6). Non- specific binding was blocked with $3 \%$ non-fat milk/0.05\% Tween 20 in PBS. After incubating samples overnight a $4^{\circ} \mathrm{C}$, plates were extensively washed, and bound antibodies were detected using goat anti-mouse IgM (1:2500); IgA-HRP (1:1000), [lgG1-HRP, IgG2a-HRP, IgG2b-HRP and IgG3-HRP conjugate to a concentration of 1:2500], followed by Streptavidin-Horseradish peroxidases conjugate (Mouse Ig isotyping ELISA, Bioscience). Color reactions were developed using Tetramethyl-benzidine in $0.05 \mathrm{~N}$ citrate-phosphate buffer (pH 5.2), supplemented with $0.01 \% \mathrm{H}_{2} \mathrm{O}_{2}$. The reaction was stopped with $1 \mathrm{M} \mathrm{H}_{3} \mathrm{PO}_{4}$. Optical densities were measured at $450 \mathrm{~nm}$ using a microplate reader. Amounts of IFN- $\gamma$, TNF- $\alpha$, IL10 , IL-4, or IL-17 in the supernatants were measured by using a specific sandwich ELISA (OptEIA; BD Bioscience BD Pharmingen ${ }^{\top M}$ ) according to the manufacturer's instructions. Assay sensitivities were $2.5 \mathrm{pg} / \mathrm{ml}$ for IFN- $\gamma$ and 3 for the other cytokines (IL-17, IL-4, IL-10). Data are expressed as the mean \pm SEM for each mouse group.

\section{Viabiility assay}

Cell monolayer of pneumocytes class II (A549) was prepared, to 10000 cells per well in a 96 plates and incubated overnight to $37^{\mathrm{a}} \mathrm{C}, 5 \%$ of $\mathrm{CO} 2$. Then, the monolayer was washed once with a HBSS solution and culture medium was added. The cells were stimulates as follow: BCG (MOI 10:1), a comercial product based on Cry1A-Cry2A toxins (Bactospeine) $(10 \mu \mathrm{g} / \mathrm{ml}), \mathrm{BCG}+$ Cry1A-Cry2A toxins (Bactospeine) (MOI 10:1). As a control of toxicity Ursolic acid $(20 \mu \mathrm{g} / \mathrm{ml})$. Negative control (medium culture). Viability of the cells were determined at 24 and $48 \mathrm{~h}$ post stimulation. At each period of time, the supernatant was discarded. Trypan blue $(0.01 \%)$ was added to the Wells. Alive and death cells were counted at light microscopy. The assays was performed by duplicate.

\section{Statistical analysis}

Statistical analysis to determine was calculated using ANOVA. Differences between the means were calculated by Tukey'test. A P value $<0.05$ was considered statistically significant.

\section{Results}

\section{Immunogenicity of a commercial based Cry1A-Cry2A toxin preparation (Bactospeine) after intranasal immunization of BALB/c mice.}

It has been reported that mice feeded with transgenic maize and /or purified Cry1Ab toxin induced humoral and cellular immune responses in serum of mice after sensitization by intraperitoneal or intragastric route. Not induction of IgE or toxicity was observed [29-30]. Herein, a commercial Cry1A based product was evaluated in vitro and in vivo, respectively. To this end, mice were immunized by oral or intranasal route with Bactospeine (Cry1A-Cry2A toxins) (Figure 1). Thus, mice immunized by oral route with Bactospeine (Cry1A-Cry2A toxins) induced humoral response significant with respect to control PBS immunized mice $(P<0.05)$ but at lower magnitude than after intranasal immunization $(P<0.05)$ (Figure 1 upper and lower panel). Thus, at systemic level, IgA $(0.57 \pm 0.042$ vs $0.36 \pm$ 
0.006) and $\operatorname{lgM}(0.54 \pm 0.028$ vs $0.35 \pm 0.0)$ (Figure 1) were elicited. While at mucosal level, $\lg A(0.50 \pm 0.016)$ and $\lg M$ $(0.54 \pm 0.008)$ were detected in BAL (Figure 1). Not difference in the lgG subclass Abs induced after oral immunization of mice with respect to those immunized by $i-n$. route either in serum or in BAL (Figure 1, upper and lower panel). However, the magnitude of these antibodies were significant with respect to control PBS immunized mice $(P<0.05)$ in seric lgG1 $(0.63 \pm 0.04$ vs $0.35 \pm 0.005) ; \lg 22 \mathrm{a}(0.59 \pm 0.02$ vs $0.36 \pm 0.0) ; \lg 22 \mathrm{~b}(0.59 \pm$ 0.014 vs $0.33 \pm 0.007)$ and $\lg G 3(0.59 \pm 0.04$ vs 0.350 .007$)(P<$ $0.05)$ (Figure 1); and in $\mathrm{BAL}, \operatorname{lgG} 1(0.53 \pm 0.03$ vs $0.36 \pm 0.005)$; $\lg 2 \mathrm{a}(0.59 \pm 0.02$ vs $0.35 \pm 0.003) ; \lg \mathrm{g} 2 \mathrm{~b}(0.59 \pm 0.014$ vs 0.33 $\pm 0.007)$ and $\operatorname{lgG} 3(0.59 \pm 0.04$ vs $0.35 \pm 0.0)$ were induced $(P<$ 0.05) (Figure 1 upper and lower panel).

Interestingly, after intranasal immunization of mice with the commercial product Bactospeine (Cry1A-Cry2A toxins) (Materials and Methods), in general the humoral response was higher and significant $(P<0.05)$ with respect to control PBS immunized mice and with respect to oral administration of this product (Figure 1 upper and lower panel). Briefly, mice immunized by intranasal route with Bactospeine (Cry1A-Cry2A toxins) elicited significant levels of systemic lgM (0.65 \pm 0.0007$)$ and $\lg \mathrm{A}_{1}(0.64 \pm 0.021)(\mathrm{P}<0.05)$ as well as $\lg \mathrm{g}$ subclass antibodies [lgG1 (0.65 \pm 0.028$) ; \operatorname{lgG} 2 \mathrm{a}(0.61 \pm 0.021)$; lgG2b (0.61 \pm 0.021); $\operatorname{lgG} 3(0.69 \pm 0.07)$ (Figure 1 upper panel) in comparison with control mice $[\operatorname{lgM}(0.35 \pm 0.0)$ and $\lg \mathrm{A}(0.36 \pm$ 0.006); $[\operatorname{lgG} 1(0.36 \pm 0.005) ; \operatorname{lgG} 2 \mathrm{a}(0.36 \pm 0.0)$; $\operatorname{lgG} 2 \mathrm{~b}(0.33 \pm$ $0.007)$; IgG3 (0.35 \pm 0.003)] (Figure 1 upper panel) $(P<0.05)$. Moreover, the magnitude of the antibody response detected in BAL induced by the intranasal immunization of mice with Bactospeine, were significant with respect to control PBS immunized mice of $\operatorname{lgM}[(0.68 \pm 0.030)$ vs $(0.36 \pm 0.007)])$ and $\operatorname{lgA}[(0.61 \pm 0.025)$ vs $(0.35 \pm 0.003)]$ (Figure 1 lower panel) $(\mathrm{P}<$ $0.05)$; while $\lg$ subclass such as $\lg \mathrm{G} 1(0.63 \pm 0.014)$; $\lg \mathrm{g} 2 \mathrm{a}(0.62$ $\pm 0.020)$; $\lg G 2 \mathrm{~b}(0.58 \pm 0.018) ; \operatorname{lgG} 3(0.71 \pm 0.010)$ were also significant $(\mathrm{P}<0.05)$ with respect to control mice [lgG1 $(0.36 \pm$ 0.018); IgG2a(0.35 \pm 0.003$) ; \lg 2 \mathrm{~b}(0.36 \pm 0.03) ; \lg \mathrm{g} 3(0.36 \pm$ $0.003)](P<0.05)$ (Figure 1 lower panel)

\section{A pattern of Th1-Th2 type cytokines as well as IL-17 and IL-10 were induced after intranasal immunization of BALB/c mice with Bactospeine (Cry1A + Cry2A toxins)}

Next, due to the cholera toxin IL-17-inducing capacity (20-21), we investigate whether the commercial products based on Cry1A-Cry2A toxins (Bactospeine) have this ability. Thus, after intranasal immunization, mice induced at systemic level; mice elicited, IFN- $\gamma(1127 \pm 396$ vs $149 \pm 9$ $\mathrm{pg} / \mathrm{ml}) ; \mathrm{IL}-17(756 \pm 96$ vs $133 \pm 6) ;$ TNF- $\alpha(5967 \pm 651$ vs $365 \pm 7)$ and IL-6 (2354 \pm 346 vs $392 \pm 7$ pg/ml) $(P<0.05)$; IL-17 (756 \pm 96 vs $133 \pm 6 \mathrm{pg} / \mathrm{ml}) ; \mathrm{IL}-10(814 \pm 85$ vs $161 \pm$ $17 \mathrm{pg} / \mathrm{ml})$. Not difference in IL-4 production with respect to control immunized mice (Figure 2l). Furthermore, at mucosal level (detected in $\mathrm{BAL}$ ), mice elicited a significant amount of IL-10 (2215 \pm 222 vs $683 \pm 5$ pg/ml $)(P<0.05)$; IL-4 (2037 \pm 261 vs $457 \pm 083 \mathrm{pg} / \mathrm{ml})(P<0.05) ; \mathrm{IL}-6(1495 \pm 254$ vs $472 \pm$ 33). IFN-Y (2165 \pm 336 vs $647 \pm 39$ pg/ml); IL-17(2136 \pm 143 vs $669 \pm 8 \mathrm{pg} / \mathrm{ml}) ;$ TNF- $\alpha(2957 \pm 277$ vs $621 \pm 11 \mathrm{pg} / \mathrm{ml})$.
Predominant IFN- $\boldsymbol{\gamma}$ production at systemic level after oral immunization of BALB/C mice with Cry1A-Cry2A toxins (Bactospeine).

After oral immunization, unexpectedly, we found that mice immunized by oral route produced a significant amount at systemic level of IFN-g (4125 \pm 707 vs $223 \pm 13)$ $(P<0.05), I L-17(1200 \pm 0$ vs $117 \pm 14) ; I L-6$ (1399 \pm 198)(P < 0.05); TNF- $\alpha(4533 \pm 378$ vs $362 \pm 35$ pg/ml); IL-10 (642 \pm 103 vs $173 \pm 21 \mathrm{pg} / \mathrm{ml}) ;$ and IL-4 (597 \pm 59 vs $180 \pm 3 \mathrm{pg} / \mathrm{ml}$ ) (Figure 2-I-II). At mucosal level (detected in BAL); a difference in magnitude was observed in IL-10 (2165 \pm 196 vs $647 \pm 47 \mathrm{pg} / \mathrm{ml})$; IL-4 (2083 $\pm 58 ; 542 \pm 162 \mathrm{pg} / \mathrm{ml})$; IL$17(2850 \pm 815$ vs $472 \pm 82) ;(P<0.05) ;$ TNF- $\alpha(2176 \pm 305 v s$ $529 \pm 17 \mathrm{pg} / \mathrm{ml})(\mathrm{P}<0.05)(\mathrm{P}<0.05)$ (Figure 2II); IFN-g(2460 \pm 353 vs $800 \pm 118 \mathrm{pg} / \mathrm{ml})$ and IL-6 (1412 \pm 172 vs $444 \pm 44$ $\mathrm{pg} / \mathrm{ml})(\mathrm{P}<0.05)$ (Figure 2ll right lower panel)

A commercial product based on Cry1A-Cry2A toxins (Bactospeine) did not affect the viability of pneumoctyes class II (A549 human cell line) in vitro.

From the above results, we prompted to pinpoint these immunogenicity in vitro. To this end, we used pneumocytes class II (A549 human cell line). First, toxicity was tested in vitro (Figure 3-I-II). Ursolic acid was used as a control of toxicity. (Figure $3 \mathrm{I}-\mathrm{II}$ ). As described in material and methods, the percentage of viability was calculated from the light microscope (Zeiss) observance using Trypan blue (Figure 3I). In comparison with Ursolic acid, no toxic effect were induced by the commercial product based on Cry1A toxins after $48 \mathrm{~h}$ after stimulation of cells $(P<0.05)$. Around $5-8 \%$ of decrease of viability was observed after $24 \mathrm{~h}$ post stimulation in comparison with control cells (stimulated with medium only $(P<0.05)$. However, the cells proliferate and restored viability was measured at $48 \mathrm{~h}$ ) in comparison with any of the stimulus, Ursolic acid, BCG or BCG + Cry (Figure 3I, II) $(\mathrm{P}<$ 0.05).

A commercial product based on Cry1A-Cry2A toxins (Bactospeine) in Pneumocytes class II (A549 human cell line) acted as an adjuvant after co-administration with M. bovis Bacillus Calmette Güerin (BCG) vaccine.

Finally, we measured the cytokines induced by the effect of stimulation of A549 epithelial human cell line cells with commercial product based on Cry1A-Cry2A toxins. We found that $A 549$ cells elicited, IL-10 [(BCG, $15140 \pm 2382$; Cry $18948 \pm 1411 ; B C G+$ Bactospeine (Cry1A+Cry2A) 17940 $\pm 707)](P<0.05)$, and IL-6 [BCG, $11450 \pm 0.0$; Cry $14825 \pm$ 355. BCG + Bactospeine (Cry1A+Cry2A toxins) $14575 \pm$ 354] ( $P<0.05)$ (Figure 4 upper panel)(gray bars). Remarkably, an increase in Th1-type cytokines such as IFN-Y (BCG, $14500 \pm 823$; Cry $17900 \pm 283$; BCG + Bactospeine (Cry1A +Cry2A toxins) $(18890 \pm 212)(P<0.05)$ and IL-12 (BCG, $102330 \pm 1838 ;$ Cry $6358 \pm 530 ; B C G+$ Bactospeine (Cry1A-Cry2A) (15150 \pm 0.0$)(P<0.05)$ (Figure 4 lower panel, dark gray bars). Not effect in IL-17 or IL-4 cytokine production. 
Figure 1

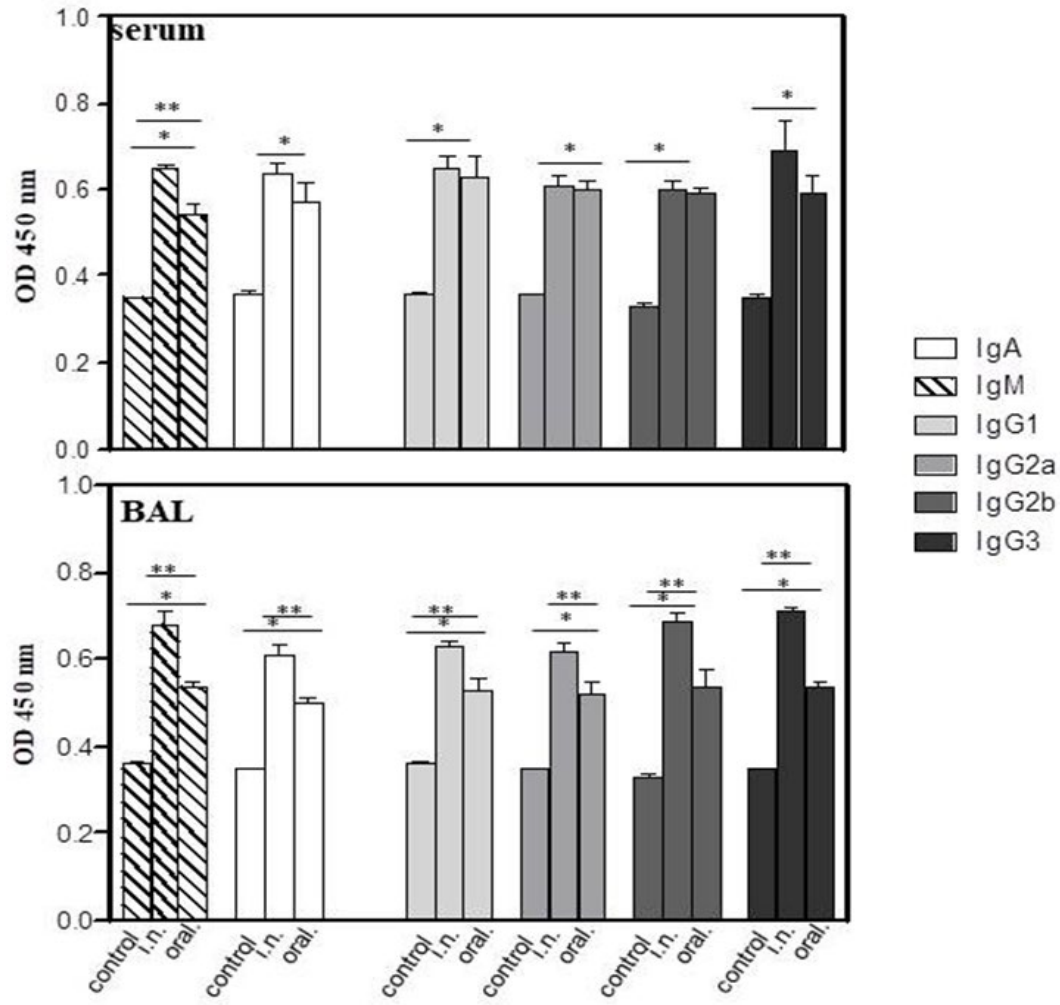

Figure 1. A commercial product based on Cry1A-Cry2A toxins (Bactospeine) acts like a strong immunogen (IgM/lgA, and IgG subclass) through intranasal (I) and after oral immunization of BALB/C mice (II). After sacrifice of mice serum and BAL washes were recovered and antibodies (mouse isotyping BD Biosciences) were detected either in serum or BAL using ELISA. Differences are significant at $\mathrm{P}<0.05$ with respect to control PBS immunized mice $\left({ }^{\star}\right)$ and between the i.n/oral routes $\left({ }^{* *}\right)$.

\section{Discussion}

Bacillus thruingiensis Cry toxins have been shown to be strong immunogens, carrier and adjuvants through different routes of immunization [4-10]. However, still there are safety and bio-ethical concerns regarding its use in agricultural and clinic use [22-28]. Herein, we are reporting that a commercial products based on Cry1A-Cry2A toxins (Bactospeine)(BD Biosciences) did not show any toxicity either in vivo or in vitro assays; on the contrary, it show a dichotomy effect, as an strong immunogen and as an adjuvant of Th1-type cytokine of $M$. bovis BCG immunity

Despite of a huge amount of evidences supporting the use of the cholera toxin subunit $B$ as a candidate vaccine adjuvant of bystander antigens [17-21], still there are concerns regarding its clinic use. Bacillus thruingiensis Cry toxins have been long used for decades for insect biological control [1-3]. In more recent years, it has been shown that pCry1Ac behaves as strong immunogen after different routes of immunization to mice [7-8]. Furthermore, $\mathrm{pCry} 1 \mathrm{Ac}$ has been demonstrated that can be used as an adjuvant of clinically important antigens [9-12]. Regarding the mechanism of action of pCry1Ac in mice, it has been proposed that the observed immunogenic properties could involve the interaction of the pCry1Ac with surface proteins localized in the small intestine microvellosity of mice [13], and a more recent study show that pCry1Ac is able to interact with HSP70 followed by signalization through the ERK pathway in macrophages [16]. The effects of pCry1Ac interaction on intestinal epithelium is that can promote the regionalization of some receptors like plgR [5] and increase the expression of FCRn in the intestinal epithelium of adult mice [14].
Bt Cry1A toxins, including tCry1Ac is comprised of three domains [1-2], one of them, domain II, is the binding domain; therefore, it is tempting to think that the observed immunogenic and adjuvant properties showed by these toxins might involve domain II of tCry1A [4]. However, not further studies have been made to assess this issue [4], [13-16]. In the present work, with focused to evaluate the non.toxicity of a commercial product Bactospeine (Cry1A-Cry2A toxins) either in vivo and in vitro assays. The data obtained, revealed that Bactospeine (Cry1A-Cry2A) did not exert any toxicity (Figure $3 \mathrm{I}-\mathrm{II}))(\mathrm{P}<0.05)$ on the contrary, through mucosal immunization, either after oral or intranasal route, elicited significant magnitude of Abs isotype (IgM and $\lg A$ ) as well as $\mathrm{IgG}$ subclass $\mathrm{Ab}$; and pro-inflammatory and antiinflammatory cytokines (Figure 1-III; 2I-II).(P < 0.05). Remarkably, after oral administration, we found that systemic IFN- $\gamma$, TNF- $\alpha$ as well as IL-17 were elicited (Figure 2II) $(P<0.05)$. Nonetheless, these cytokines were also induced at mucosal level (BAL) even at lesser magnitude (Figure 2I-II). Furthermore, these cytokines were also induced at mucosal level (BAL) even at lesser magnitude (Figure 2I-II). Furthermore, potential Bactospeine immunogenic properties were strengthened because after in vitro co-stimulation of pneumoytes class II (A549 human cell line)(Figure 4I-II), exerted an adjuvant activity of the BCG vaccine Th1-type inducing immunity (IFN-g, IL-12) Figure 4-II, $p<0.05$ ), an ability that is being currently addressed. In summary, the data reported in this work, highlight a novel property of commercial product based on Cry1A-Cry2A toxins (Bactospeine) as immunogen and more important as an adjuvant, which open a potential alternative to be taken in account for the development of non-toxic subunits agents in infectious disease and other chronic human diseases. 
Figure 2

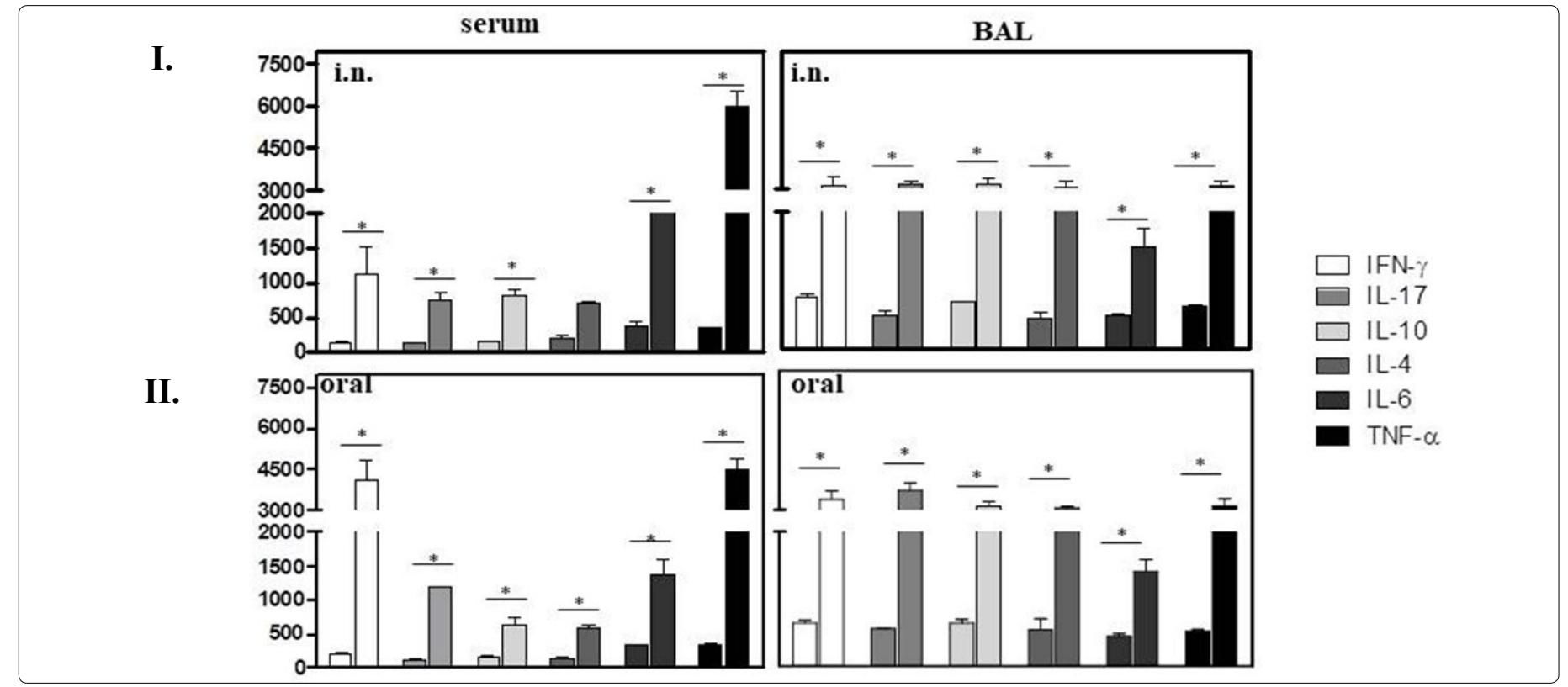

Figure 2. A pattern of Th1, Th2 and Th3 cytokines are elicited after intranasal (I) and oral immunization (II) of mice with a commercial product Cry1A-Cry2A toxins (Bcatospeine). After the third of immunization, mice were sacrificed and serum and BAL washes were recovered. Cytokine production were measured by ELISA. Values are expressed in $\mathrm{pg} / \mathrm{ml}$ and represent media \pm SEM of samples tested in duplicates from each group of mice. Differences are significant at $P<0.05$ with respect to control PBS immunized mice $\left({ }^{\star}\right)$ for Abs and cytokines and between the i.n/oral routes ${ }^{* \star}$ ) (for Abs only).

Figure 3

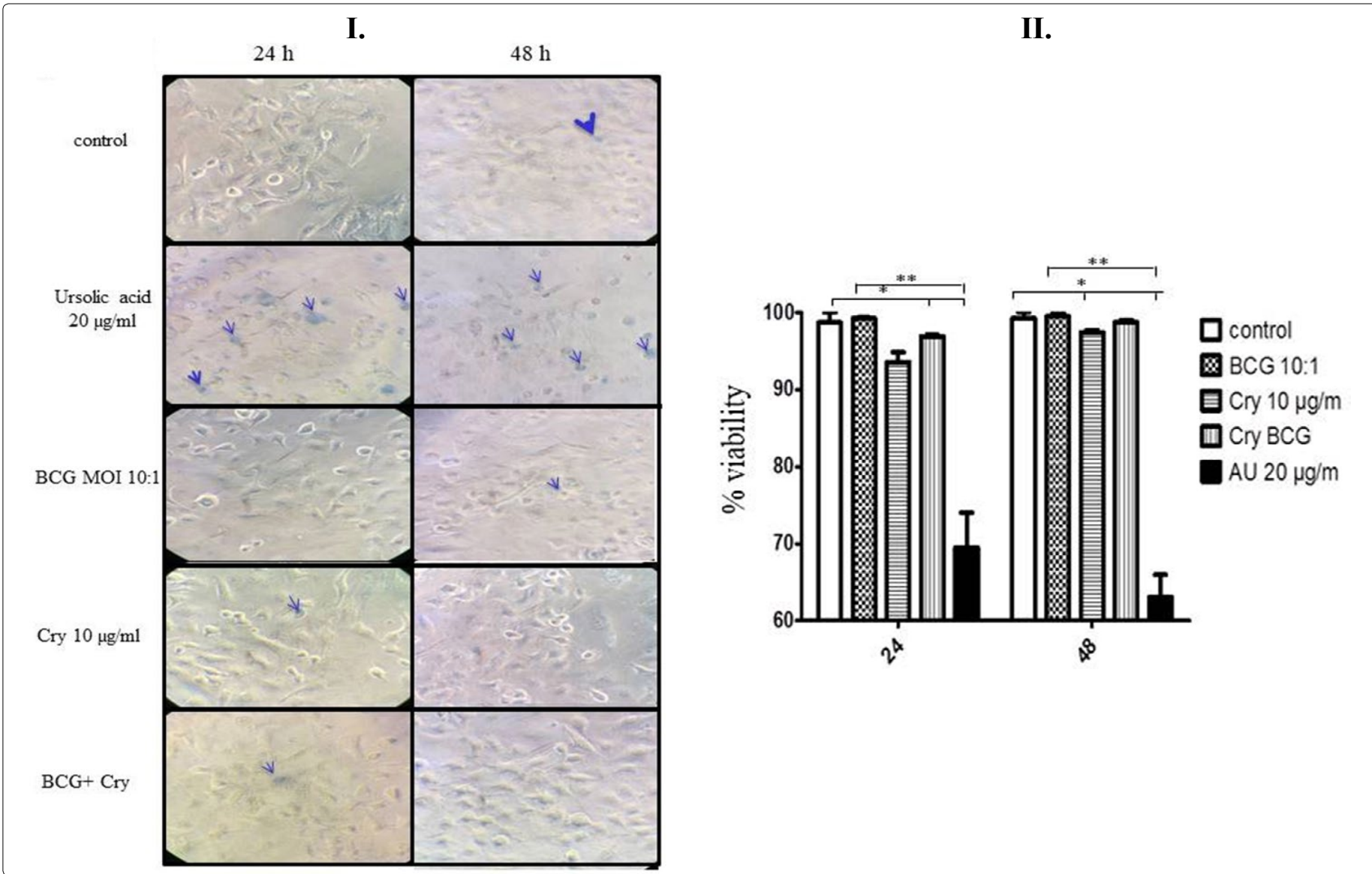

Figure 3. A commercial product based on Cry1A-Cry2A toxins (Bactospeine) is not toxic to pneumocytes class II (A549 human cell lines). To assess the toxicity of the mentioned formulation, a monolayer of A549 cells were stimulated as follow: BCG (MOI 10:1), Cry protein (10 $\mu$ g/ $\mathrm{ml}), \mathrm{BCG}+\mathrm{Cry}(\mathrm{MOI} 10: 1)$. As a control of toxicity, ursolic acid $(20 \mu \mathrm{g} / \mathrm{ml})$ was used. Negative control (medium culture). Viability of the cells were determined at 24 and $48 \mathrm{~h}$ respectively, aftet stimulation. Thereafter each time, the supernatant was discarded. Trypan blue (0.01\%) was added to the wells and alive and death cells were counted at light microscopy. The assays was performed by duplicate. Differences are significant at $\mathrm{P}<0.05$ with respect to control PBS immunized mice $\left({ }^{*}\right)$ and with respect to ursolic acid $\left({ }^{*}\right)$. 
Figure 4

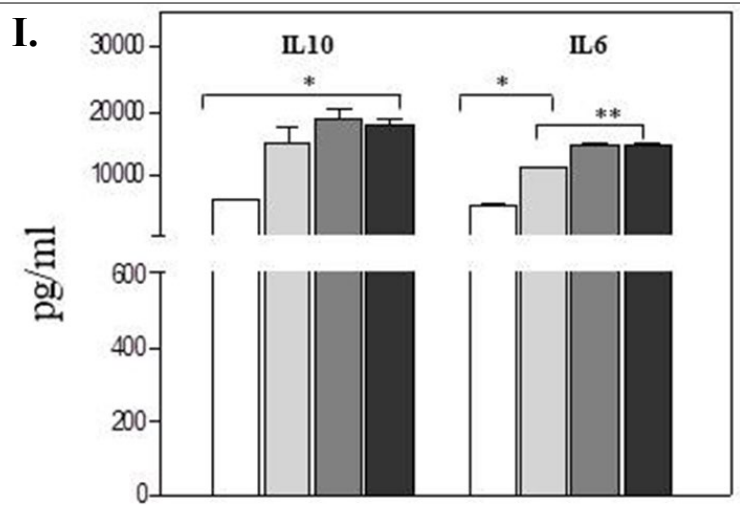

II.

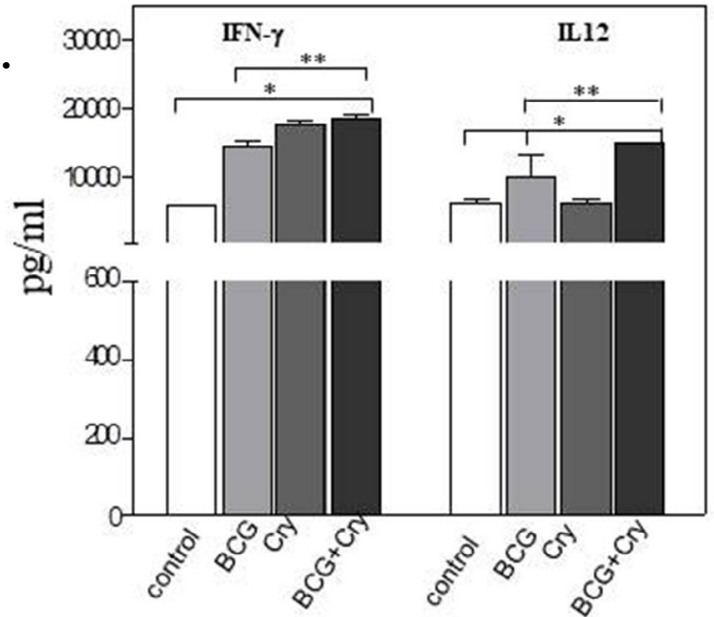

Figure 4. A commercial product based on Cry1A-Cry2A toxins (Bactospeine) boosted the BCG vaccine Th1 type cytokine production in vitro. Pneumocytes class II (A549 cells) were co-stimulated as described in mat and methods. Cytokine production (IL10, IL-6, IFNY, IL-12, IL17) (BD Biosciences Pharmingen ${ }^{\mathrm{TM}}$ were measured in the supernatant of the cell culture of each treatment and measured by ELISA. Values are expressed in $\mathrm{pg} / \mathrm{ml}$ and represent media \pm SEM of samples tested in duplicates from each group of mice. Differences are significant at

$\mathrm{P}<0.05$ with respect to control PBS immunized mice $\left({ }^{*}\right)$ and with respect to BCG vaccination without boost $\left({ }^{* *}\right)$.

Disclosure of statement: The authors declare no conflict of interest.

Acknowledgements: The present work was supported by SEP (Programs; PRODEP, PIFI, PERFIL-PRODEP), and SNI CONACYT. The authors are grateful for the technical assistance of the members of the immunobiology lab group from ENCB.IPN. Mexico, City.

\section{References}

1. Bravo A. Phylogenetic relationships of Bacillus thruingiensis d-endotoxin family proteins and their functional domains. J. Bacteriol. 1997; 179: 2793-2801.

2. De Maagd RA, Bravo A, Crickmore N. How Bacillus thruingiensis has evolved specific toxins to colonize the insect world. Trends Genet. 2001; 17: 193-99.

3. López PL, Soberón M, Bravo A. Bacillus thruingiensis insecticidal theedomain Cry toxins: mode of action, insect resistance and consequences for crop protection. FEMS Microbiol Rev. 2013; 37: 3-22. doi: 10.1111/j.1574-6976.2012.00341.x

4. Guerrero GG, Dean DH, Moreno-Fierros L. Structural Implication of the induced immune response by Bacillus thruingiensis Cry proteins: role of the N-terminal region. Mol. Immunol. 2004; 41: 1177-83. doi: 10.1016/j. molimm.2004.06.026

5. Guerrero GG, Russell WM, Moreno-Fierros L. Analysis of the cellular immune response induced by Bacillus thruingiensis Cry $1 \mathrm{~A}$ toxins in mice: effect of the hydrophobic motif from diphtheria toxin. Mol Immunol. 2007; 44: 1209-17. doi: 10.1016/j.molimm.2006.06.007
6. Guerrero GG, Moreno-Fierros L. Carrier potential properties of Bacillus thruingiensis Cry1A toxins for a diphtheria toxin epitope. Scandinavian. Journal of Immunology. 2007; 66: 610-18. doi: 10.1111/j.1365-3083.2007.01992.x

7. Vázquez-Padrón ROI, Moreno-Fierros L, Neri-Bazán L, de la Riva GA, López Revilla. Intragastric and intraperitoneal administration of Cry1Ac protoxin from Bacillus thruingiensis induces systemic and mucosal antibody responses in mice. Life Science. 1999; 64(1): 1897-12.

8. Moreno-Fierros L, García N, Gutiérrez R, López-Revilla R, Vázquez-Padrón RI. Intranasal, rectal and intraperitoneal immunization with protoxin Cry $1 \mathrm{Ac}$ from Bacillus thruingiensis induces compartmentalized serum, intestinal, vaginal and pulmonary immune responses in Balb/c mice. Microbes Infect. 2000; 2(8): 885-90. doi: 10.1016/S1286-4579(00)00398-1

9. Moreno-Fierros L, Ruiz-Medina EJ, Esquivel R, López-Revilla R, Piña-Cruz $S$. Intranasal Cry1Ac protoxin is an effective mucosal and systemic carrier and adjuvant of Streptococcus pneumoniae polysaccharides in mice. Scand J Immunol. 2003; 57: 45-55.

10. Moreno-Fierros L, García-Hernández AL, Ilhuicatzi-Alvarado D, et al. The protoxin Cry1Ac of Bacillus thruingiensis improves the protection conferred by intranasal immunization with Brucella abortus RB51 in a mouse model. Vet Microbiol. 2013; 17: 1051-66. doi: 10.1016/j. vetmic.2014.11.021

11. Ibarra-Moreno S, García-Hernández AL, Moreno-Fierros L. Coadministration of protoxin Cry1Ac from Bacillus thruingiensis with metacestode extract confers protective immunity to murine cysticercosis. Parasite Immunol. 2014; 36: 266-70. doi: 10.1111/pim.12103.

12. González-González E, García-Hernández AL, Flores-Mejía R, López-Santiago $\mathrm{R}$, Moreno-Fierros $\mathrm{L}$. The protoxin Cry1Ac of Bacillus thruingiensis improves the protection conferred by intranasal immunization with Brucella abortus RB51 in a mouse model. Vet Microbiol. 2016; 175: 382-8. doi: 10.1016/j. vetmic.2014.11.021 
13. Vázquez-Padrón ROI, González-Cabrera J, García TC, et al. Cry1Ac protoxin from Bacillus thruingiensis sp kurstaki HD 73 binds to surface proteins in the mouse small intestine. Biochem. Biophys. Res. Commun. 2000; 271(1): 54-58. doi: 10.1006/bbrc.2000.2584

14. Verdin-Teran, SL,Vilches-Flores A L. Moreno-Fierros. Immunization with Cry1Ac from Bacillus thruingiensis Increases Intestinal IgG Response and Induces the Expression of $\mathrm{FcRn}$ in the Intestinal Epithelium of Adult Mice. Scandinavian Journal of Immunology. 2009; 70: 596-607. doi: 10.1111/j.1365-3083.2009.02332.x

15. Reséndiz-Albor AA, Reina-Garfias $H$, Rojas-Hernández $S$, Jarillo-Luna $A$, Rivera-Aguilar V, Miliar-García A. Regionalization of plgR expression in the mucosa of mouse small intestine. Immunol Lett. 2010; 128: 59-67. doi: 10.1016/j.imlet.2009.11.005

16. Rubio-Infante $N$, Ilhuicatzi-Alvarado $D$, Torres-Martínez $M$, ReyesGrajeda JP, Nava-Acosta R, González-González E. The Macrophage Activation Induced by Bacillus thruingiensis Cry1Ac Protoxin Involves ERK1/2 and p38 Pathways and the Interaction with Cell-Surface-HSP70. J Cell Biochem. 2018; 119: 580-98. doi: 10.1002/jcb.26216

17. Nalin DR. Cholera and severe toxigenic diarrhoeas. Gut. 1994; 35(2): 14549.

18. Tamura $S$, Samegai $Y$, Kurata $H$, Nagamine $T$, Aizawa $C$, Kurata $T$. Protection against influenza virus infection by vaccine inoculated intranasally with cholera toxin B subunit. Vaccine. 1988; 6: 409-13.

19. Rask C, Fredriksson M, Lindblad M, Czerkinsky C, Holmgren J. Mucosal and systemic antibody responses after peroral or intranasal immunization: Effects of conjugation to enterotoxin $B$ subunits and/or of co-administration with free toxin as adjuvant. APMIS. 2000; 108: 178186. doi: 10.1034/j.1600-0463.2000.d01-42.x

20. Jee-Boong L, J-Eun J, Man-Ki S, Chang J. Intranasal delivery of cholera toxin induces TH17-dominated T-Cell response to bystander antigens. PLOS ONE. 2009; 4(4): e5190. doi: 10.1371/journal.pone.0005190

21. Datta SK, Sabet M, Nguyen KPL, Valdéz PA, González-Navajas JM, Islam S. Mucosal adjuvant activity of cholera toxin requires Th17 cells and protects against inhalation anthrax. PNAS. 2010; 107: 10638-643. doi: 10.1073/pnas. 1002348107
22. Rubio-Infante N, Moreno-Fierros L. An overview of the safety and biological effects of Bacillus thruingiensis Cry toxins in mammals. J Appl Toxicol. 2016; 36: 630-48. doi: 10.1002/jat.3252.

23. Tayabali S. Human cell exposure assays of Bacillus thruingiensis commercial insecticides production of Bacillus cereus-like cytolytic affects fro, outgrowth of spores. Environ Health Perspect. 2000; 108: 91930. doi: 10.1289/ehp.00108919

24. Shimada N, Miyamoto K, Kanda K, Murata H. Bacillus thruingiensis insecticidal Cry1ab toxin does not affect the membrane integrity of the mammalian intestinal epithelial cells: An in vitro study. In vitro Cell Dev Biol Anim. 2006; 42: 45-9. doi: 10.1290/0506042.1

25. Schrøder M, Poulsen M, Wilcks A, Kroghsbo S, Miller A, Frenzel T, et al. A 90-day safety study of genetically modified rice expressing Cry $1 \mathrm{Ab}$ protein (Bacillus thruingiensis toxin) in Wistar rats. Food Chem Toxicol. 2007; 45: 339-49. doi: 10.1016/j.fct.2006.09.001

26. Finamore $A$, Roselli $M$, Britti $S$, Monastra $G$, Ambra R, Turrini A. Intestinal and peripheral immune response to MON810 Maize ingestion in weaning and old mice. J. Agric. Food Chem. 2008; 56(23): 11533-539. doi: 10.1021/jf802059w

27. Adel-Patient K, Guimaraes VD, Paris A, et al. Immunological and Metabolomic impacts of Administration of Cry $1 \mathrm{Ab}$ protein and MON 810 Maize in mouse. Mice Cry1Ab. PLoS ONE. 2011; 6: e16346. doi: 10.1371/journal.pone.0016346

28. Seralini GE, Clair $E$, Mesnage $R$, Long term toxicity of a roundup herbicide and a round up-tolerant genetically modified maize. Food and Chemical Tox. 2012; 50(11): 4221-31. doi: 10.1016/j.fct.2012.08.005

29. Texeira-Correa RF, Mendes-PD, Araujo A, Gomes MR, Morais RB. Cytotoxicty analysis of three Bacillus thruingiensis subsp. Israelensis d-entodoxin towards insect and mammalian cells. PLOS ONE. 2012; 7 : e46121. doi: 10.1371/journal.pone.0046121

30. Poletto MB, Miranda-Vilela AL, Kuppe GC B. Toxicological evaluation of a potential immuosensitizer for use as a Mucosal Adjuvant-Bacillus thruingiensis Cry1Ac spore-crystals: A possible inverse agonist that deserves further investigation. Toxins. 2015; 7(12): 5348-58. doi: 10.3390/ toxins 7124881 